\title{
THE LAMBETH CONFERENCE*
}

7 HE report of the Lambeth Conference of 1920

1 will be read by all thinking men and women with interest. Catholics will not be slow in recognizing its importance. They can regard it dispassionately, for with it they are hardly personally concerned.

Reunion with Rome is referred to by the Conference only once, and it is immediately put out of court. It is not within practical politics. The one reference, however, is worthy of its object. Ultimately reunion without Rome is an impossibility. Every successive Lambeth Conference will echo the substance of this declaration.

We had debated within our minds what the $25^{2}$ Bishops in communion with the see of Canterbury would agree on in their report.

Without doubt the Conference marks a great and perhaps far-reaching event in the history of its church. It presents a new view of the church, and with some detail unfolds its scheme of reunion.

We cannot accuse it of unnecessary vagueness. It is as definite as a new-born scheme can be. It is concrete and intelligible. The plan is simple. Perhaps that is one of its faults. It may be found unworkable, too humanly devised, too easily destroyed, too willingly abandoned. The Conference certainly disclaims any intention of speaking with any final authority, but as a final authority seems impossible to be found, we presume that the practical unanimity of 252 Bishops will carry a weight by no means inconsiderable.

The report is worthy of a patient reading. It should be read and re-read. It is undoubtedly the work of able-minded men conscious of their responsibilities, and alive to the need of action. Their Rome is on

* Conference of Bishops of the Anglican Communion.

(S.P.C.K., London).

3I8 


\section{The Lambeth Conference}

fire : at least they will not fiddle. Nay, the world is on fire, and may be destroyed : they will at least confer and invoke God's aid.

The Church to which they belong is disorganized. The elements of English-speaking Christianity are scattered and therefore effete. Cannot they close their ranks, unite or rather coalesce, live in the greater unity, the Anglican Church, live there their own denominational life, having received "the Apostolic rite of the laying on of hands "?

In the deep gravity of its proceedings, in its sweet reasonableness, in its remembrance of holy and familiar words and names, in its presentation of an ideal undoubtedly attractive and inspiring, in its utter abstention from hurtful and injurious words, in its endeavour to face questions of real moment, problems of unmistakable perplexity, in its unrest and dissatisfaction with the way and degree it has hitherto dealt with them, there is much to evoke sincere sympathy.

And readily may we believe in the goodness of the motives inspiring this Conference. Surely the law of self-preservation finds its expression here as elsewhere ; but is it not a duty to live, if one can do so, honourably and usefully?

Catholics know for certain that this reunion will not work, for it is not reunion. Even this partial reunion without Rome is an impossibility. If it were achieved, it would be a reunion of Form not of Substance. Unconsciously to themselves it would be mere window-dressing. It would be, even in times of peace and when prejudices slumber, only a big Appearance. A ceremony, a submission to a "laying on of hands," would not create Unity.

After a few introductory remarks of a theological nature the Conference seems to avoid theology. Its absence is weird and eerie. Its absence spells danger and prophesies disaster. The Church is the pillar 


\section{Blackfriars}

and foundation of Truth. She has Truth in herself, truth elsewhere is a reflection of that Truth. She does not find it outside of herself but reflected there. It is in her own heart that she must ponder these things. The Church $i$, she has not to be made. Her unity is her life. Her sufficiency is from God, and He has provided her with all things necessary.

We are reminded of some words of Soloviev. They reach to the root of our sad controversies, and pierce to the depths of our ignorance :

"A church was to be erected, and the architect before going away, traced out the general plan and laid the foundations. To his pupils he said : 'I leave you the firm foundations that I have laid, and the general outline that I have drawn. That will be enough to guide you if you are faithful to your duty. Moreover, I shall not forsake you, but shall be ever with you in thought and spirit.'

Soon afterwards the workmen began to quarrel; some said they might as well leave the foundations already laid, and build a church elsewhere, keeping the original design. In the heat of their argument the men went so far as to assert (contrary to their real opinion, frequently manifested) that the architect never laid or even planned any foundations for the church. Others proposed to put off the building of the church till the master should return. Many workmen, after vain attempts to build in another place, gave up work altogether, and the most zealous among them devoted their life to thinking over the plan for an ideal church, whilst the majority were contented with thinking of it once a week. However, even amongst these separatist labourers, there were some who remembered the great architect's words : 'These are the firm foundations I have laid, and my church is to be built on them.' And one man said to the others, 'Let us acknowledge ourselves to be wrong, 


\section{The Lambeth Conference}

and let us do justice and give honour to our comrades, and join them in rearing the great building already begun. We must all work together if it is to be completed on the proper foundations.' This man's speech seemed strange to most of his fellows, some of whom called him Utopian, whilst others accused him of pride and presumption. But the voice of conscience told him clearly that his absent master was with him in spirit and truth."

It is the great Slav speaking, but the thought is to be traced back to a greater than Soloviev. "Let every man take heed how he buildeth. For other foundation no man can lay but that which is laid, Jesus Christ."

Norbert Wylie, O.P. 